\title{
Influential Determinants of International Students' Satisfaction in Higher Education
}

\author{
Nureezan Daud, Noor Azman Ali, Amer Hamzah Jantan
}

\begin{abstract}
It has been argued that international students' satisfaction level is crucial in measuring HEIs performance in the globalized higher education market. However, as satisfaction level is hard to define because it is based on students' perception and experience, there is a need for HEIs to continually investigate and identify the factors that contribute to students' satisfaction. Hence, this study seeks to identify the influential determinants of international students' satisfaction in higher education and to examine the relationships between perception, costs, reputation, lecturers' expertise, learning environment, facilities and course structure towards international students' satisfaction. A total of 281 international postgraduate students at public HEI in Malaysia participated in this study. Data of this study was to examine using the Multiple Regression Analysis. Results of the study revealed learning environment factor as the most influential determinant of international students' satisfaction. Results also proved that except for costs and reputation, other service quality factors namely, perception, lecturers' expertise, facilities, learning environment, and course structure were found to influence international students' satisfaction significantly. This study provides insights to HEIs to better design their internationalization strategies and bridge the academic gap by highlighting the importance of continuously improving the learning environment in HEIs to increase international students' satisfaction.
\end{abstract}

Keywords: Higher education, internationalization, internationalization strategy, international student, service quality, student's satisfaction.

\section{INTRODUCTION}

The demands of globalization, the rapid growth of the economy, the advanced development in higher education, and the increasing number of mobility across countries had affected the global higher education sector. Globalization had forced Higher Education Institutions (HEIs) across countries to become a market-driven organization which focuses on students' satisfaction to compete and sustain in the globalized higher education market. Past researches have proven that the ability of HEIs to increase their international students' satisfaction level would profoundly influence their strength to attract prospective students.

As students are HEIs' primary customers in the higher education sector, delivering a higher quality education service that meets students' expectation is vital in determining the students' satisfaction level. As they usually pay for tuition fees, it is reasonable for students to expect high-quality products and services in return for their money

Revised Version Manuscript Received on September 16, 2019.

Nureezan Daud, Faculty of Economics and Management, Universiti Putra Malaysia, Selangor, Malaysia.

Noor Azman Ali, Department of Management and Marketing, Universiti Putra Malaysia, Selangor, Malaysia.

Amer Hamzah Jantan, Department of Management and Marketing, Universiti Putra Malaysia, Selangor, Malaysia
[1]. Moreover, with the growing number of established HEIs around the world, students are becoming more demanding and selective. Hence, the ability of HEIs to match and meet students' perception and expectations with the actual positive experience during the study period will determine the probability of increasing the existing students' satisfaction level and also attract more prospective students' enrolment Therefore, it is vital for HEIs to understand the students' needs and expectation so that they could continuously develop effective measures in delivering a higher quality of education services to increase students' satisfaction, within their strengths, capabilities, and resources. In doing so, HEIs will be able to attract more prospective students, retaining currently enrolled students and competing in the global higher education market [2].

Many researchers have conducted studies about services quality factors that influence international students' satisfaction previously. However, there are limited studies on how service quality of higher education influences students' satisfaction in the Malaysian higher education context. Looking at the vast and rapid higher education growth in Malaysia, it will be to the best interest of Malaysian HEIs to know the services quality factors that will influence international students' mobility decision and satisfaction level so that they could become more visible in the marketplace as compared to other HEIs within the ASEAN region and beyond. Besides, greater understanding is needed on the factors that are considered relevant and essential in measuring the international students' satisfaction as well as whether or not the Malaysian HEIs service quality has any influence on international students' satisfaction. Hence, this study focus on identifying the services quality factors in higher education which profoundly influence international students' satisfaction level and investigates the relationship between perception, costs, reputation, lecturers' expertise, learning environment, facilities, course structure, and international students' satisfaction. Hence, the research is seeking answers to the following questions:

- Which service quality factors of higher education profoundly influence international students' satisfaction level?

- What are the relationships between perception, costs, reputation, lecturers' expertise, learning environment, facilities, course structure with international students' satisfaction? 


\section{LITERATURE REVIEW}

\section{A. Service quality and students' satisfaction}

The Expectancy Disconfirmation Theory describes a user's satisfaction level as a measure of differences between what the user has initially believed before buying a product or services with the experience after obtaining it [3]. Similarly, proposed in [4], regarding Expectancy Disconfirmation Paradigm, if the experience of buying exceeds initial beliefs, users will be satisfied, but if the buying experience fails to meet expectations or lower than expectations, users will be dissatisfied. Hence, a positive buying performance of a product or services will increase the user's satisfaction level. The degree of satisfaction level would also determine the degree of student's loyalty behaviors and the willingness to promote the university to others [5]. debatable and vague because students' satisfaction level consists of several dimensions and may change accordingly based on the actual learning experience and quality of education services received at HEIs [6]. Moreover, identifying the factors that contribute to students' satisfaction has also proven to be challenging and highly contextual because satisfaction level and loyalty behavior vary according to students' perception and experience. Students' perception regarding the quality of higher education might differ according to their demographic and personal background. Student's perception is vastly influenced by factors including study location, financial status, age, family education, and study environment, type of university, financial status, proven study success, gender, and age [7], [8]. On the other hand, students' learning outcomes rely on their perceptions of the quality of higher education, involvement with others, and emotional conditions [9]. The students' overall satisfaction will increase if the students' learning outcome and their study experience exceed their perception. Hence, the less likely the students will have the intention to drop out of their study. Despite that, the perceived value gained from the education experience is vital in measuring the students' satisfaction. The students' satisfaction will increase if they perceived that what they get in return is more than what they must sacrifice in the education process [10] and it will also critically determine changes in international students' perception and behavioral intentions [11]. Thus, as it is challenging to set a standard definition of students' satisfaction, continuous improvement of service quality that emphasizes on managing students' satisfaction is vital for HEIs to build their reputation and brand name.

Proven in [12], students' satisfaction level is a result of multiple factors that the students experience during the study process and not merely determined by a single service quality factor. The dimension and focus of the students' satisfaction may change over time and using the same aspect of a students satisfaction in different geographical areas and different time may yield contradictory results. Hence, as a certain measurement of the students' satisfaction may also include problems such as bias response rate, misleading questions or bad response timing that may result in an inaccurate result, researchers should continuously improve the measurement of students' satisfaction.
Nevertheless, the definition of service quality is complex,

In addition, to increase students' satisfaction, HEIs should regularly monitor and emphasize on students' expectations, needs, and interests when designing programs, courses, and course outlines and periodically monitor their performance in meeting the students' expectation and perception. Satisfied students with a good experience during their study will help promote the HEI to other prospective international students in the future [13], [14]. Eventually, it will also benefit HEIs in the long run in terms of their ability to attract more students, improve retention rate, stabilize the financial situation and heighten the overall quality and performance and distinguished themselves from other competitors [11].

\section{B. Hypotheses development}

In terms of perception, the overall impression and perception of HEIs, education, and service quality are the most influential indicator in measuring students' satisfaction [15]. Students who have positive perceptions of the university's academic factors such as quality of teaching, skills, knowledge acquired, curriculum, programs offered and access, and also non-academic factors such as the students' expectation and perception of a HEI and the students' feeling of belonging to the HEI will have a significant relationship with their overall satisfaction level. Positive perceptions may lead to satisfaction towards the overall academic experience and vice versa [16], [17]. Hence, it is hypothesized that:

H1: There is a significant relationship between perception and international students' satisfaction.

Pertaining to costs, in [18] proved that international students choose an institution based on their measurement of the overall costs of education. Demonstrated in [19], tuition fees are significantly related to international students' mobility decision and have a significant impact on enrolment rates [20]. Also, in [21] also suggest that the availability of financial assistance will enable students to manage their education costs better and have shown to be positively related to students' satisfaction. Therefore, it is hypothesized that:

H2: There is a significant relationship between costs and international students' satisfaction.

Regarding reputation, international students choose an institution based on its reputation and courses offered as they believed that graduating from a reputable university will provide them better chances of getting well-paid jobs in the future [18]. Therefore, they carefully choose a university which has a reputable brand name so that it will merge with their self-identity and they could create a decent social recognition upon graduation due to the established university's brand name [22]. University's reputation was asserted to be significantly related to university's brand name, brand meaning and brand identity [23] where university's reputation and ranking in the recognized global ranking system is also one of the critical factors that international students measure when choosing an institution to further their studies [24]. Also, in [25] proved that there is a positive relationship between international student's perception and 
expectation on teaching quality and ranking of universities with satisfaction level. Similarly, in [26], [27] stated that university's image and organizational identification was the most influential factor in determining the students' satisfaction in higher education because satisfied students in terms of their educational experience will demonstrate high loyalty to the university and also resulting in their willingness to promote the institution to others. Henceforth, in this study, it is hypothesized that:

H3: There is a significant relationship between reputation and international students' satisfaction.

Next, concerning lecturers' expertise, in [28] proposed that teachers' expertise is the most influential factor and have a significant and positive impact on student's satisfaction. Also, in [15], suggested that lecturers' expertise and lecturers' interest in the subject matter were significantly related to students' overall perception of the education quality which will also influence the students' satisfaction level. Hence, the following hypothesis is asserted:

H4: There is a significant relationship between the lecturers' expertise and international students' satisfaction.

Next, facilities is found to have a significant relationship with the students' satisfaction level whereby social conditions such as sports facilities, university canteen, coffee bars, parking spaces, and subsidized accommodation primarily contribute to the students' satisfaction as the students' campus life is a significant factor in pursuing higher facilities have more impact on students' satisfaction than other factors, namely, advice, curriculum, financial assistance, and tuition costs. Similarly, there is a positive correlation between university facilities and services with overall satisfaction [29]. Therefore, it is hypothesized that:

H5: There is a significant relationship between facilities and international students' satisfaction.

Subsequently, on the subject of learning environment, HEIs staff members who are kind, considerate and responsive, lecturers with better teaching quality [30] and the ability of faculty members to create a classroom that supports multicultural diversity [31] will create a progressive and better learning environment and higher quality of education, which, eventually will lead to a higher level of students' satisfaction. Students who are satisfied with the teaching quality and the HEIs management would likely promote the institution in the future [5], [32]. Consequently, it is hypothesized that:

H6: There is a significant relationship between the learning environment and international students' satisfaction.

Finally, vis-à-vis course structure, in [33] proposed that the applicability of study courses for practical uses are significant to increase the students' satisfaction. On the other hand, in [34] proposed that teaching quality, assessment quality, and academic program curriculum is positively associated with a students' academic satisfaction. Therefore, the following hypothesis is proposed: education [7]. Also, in [21] provided empirical evidence that

H7: There is a significant relationship between course structure and international students' satisfaction.

Hence, this study focuses on determining the direct relationships between perception, costs, reputation, lecturers' expertise, facilities, learning environment, and course structure towards the international students' satisfaction and on determining which services quality factor that profoundly influences international students' satisfaction.

\section{RESEARCH FRAMEWORK}

Based on the literature review discussed earlier, this study incorporated services quality factors of perception, costs, reputation, lecturers' expertise, learning environment, facilities and course structure (independent variables) to examine the direct relationships towards influencing international students' satisfaction (dependent variable) as illustrated in Fig. 1.

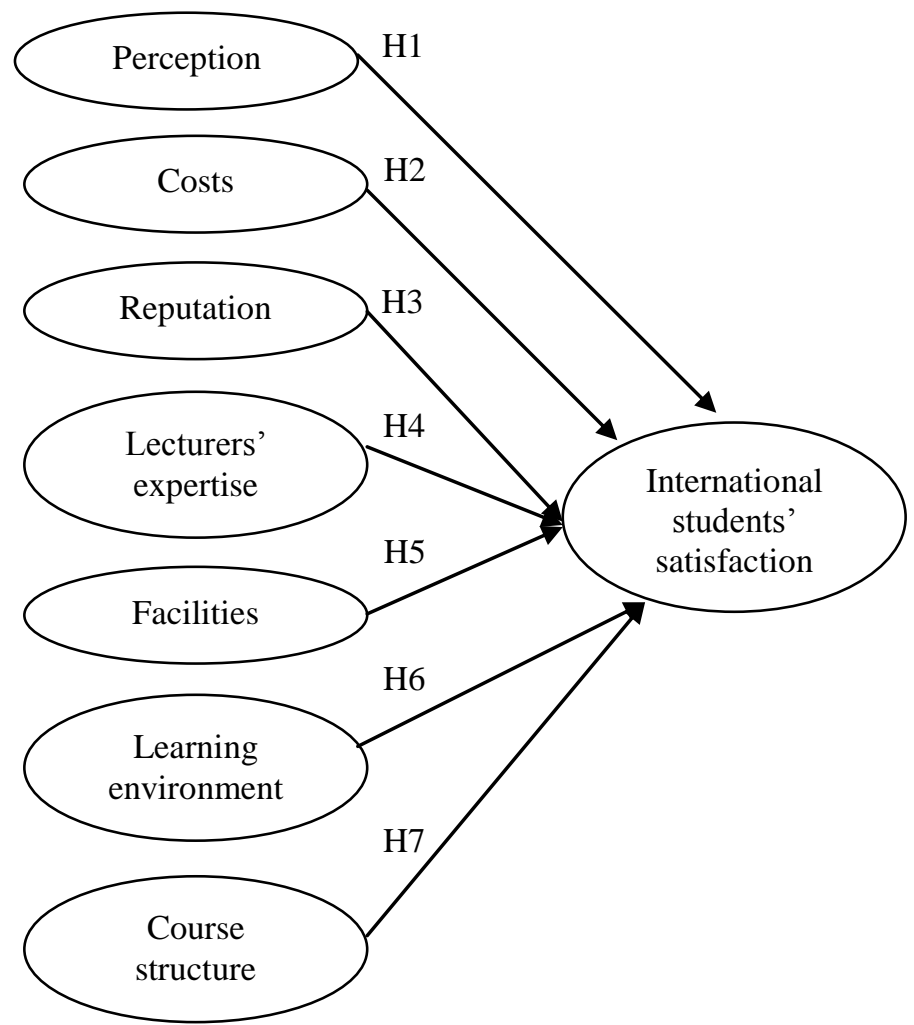

Fig. 1: Research framework [14], [28], [35]

\section{METHODOLOGY}

This study involved a quantitative approach where the current study conducted a survey using a questionnaire as the research instrument. Survey research was used in this study because it could produce a good response at a faster rate and less costly [36]. Measurements used in the questionnaires were developed based on adaption from the previously validated study from [14], [17], [35], [37]. Respondents were requested to rate their opinions and evaluations regarding the quality of product and services provided with regards to the service quality factors of perception, costs, reputation, 
lecturers' expertise, learning environment, facilities, and course structure, in order to determine the degree of satisfaction towards the overall services quality of higher education. A 7-point Likert scale ranging between the range of 1 (Strongly Agree) to 7 (Strongly Disagree) was used instead of the 5-point Likert scale because it may improve the reliability and validity of the questionnaire [38].

In this study, respondents were chosen by using convenience sampling method. The objective of using convenient sampling is to seek information from respondents who are willing to contribute and can be accessed quickly to the researcher [39]. Therefore, available and willing to participate, international postgraduate students who have at least completed two semesters at public universities in Klang Valley, Malaysia were selected so that they will be able to evaluate the quality of the services based on their initial perception and experiences and can answer accurately on their satisfaction level. Sampling size estimation was determined by using a sampling technique software named $\mathrm{G}^{*}$ Power, which proposed a total sample of 98 [40].

Out of the 500 questionnaires distributed, $83 \%$ (415) questionnaires were returned, and $17 \%$ (85) questionnaires were unreturned. From the returned questionnaires, a total of 281 completed questionnaires were coded and analyzed, while 134 questionnaires were rejected as the respondents did not complete the survey. Therefore, based on [41], the total of 281 completed questionnaires was acceptable as compared to previous researches in the same field and can be categorized as a good number of sampling. To analyze the data, a statistical analysis program which was widely used in social science study, namely IBM SPSS version 22 . The data were analyzed using the frequency analysis, reliability analysis, descriptive analysis, Pearson correlation analysis, and multiple regression analysis.

\section{RESULTS AND DISCUSSION}

For this study, data were collected from 281 postgraduate international students who were studying at public HEIs in Klang Valley, Malaysia. Most of the respondents came from Asian countries $(56.58 \%)$, followed by African countries (40.21\%), 2.85\% from European countries and $0.36 \%$ from North American country.

In terms of gender, respondents comprise of $74.7 \%$ males and $25.3 \%$ females. In terms of age, $36.7 \%$ of the respondents were between less than 25 years old, followed by the 31-35 old range $(27.4 \%), 23.8 \%$ falls in the category of above 35 years old and $12.1 \%$ are between the 26 to 30 years old range.

Out of 28 respondents, $29.5 \%$ were from UPM, followed by $22.8 \%$ from UM, $18.9 \%$ from IIUM, $18.1 \%$ from UKM and $10.7 \%$ from UUM, KL Branch. In terms of the level of study, this study revealed that $45.9 \%$ were studying at the master's degree, 53\% were studying at the Ph.D. level, and $1.1 \%$ were studying at postgraduate level. Analysis, according to the study courses, revealed that $40.6 \%$ of total respondents were enrolled in social sciences courses, followed by $21.4 \%$ enrolled in sciences courses. Another $20.6 \%$ enrolled in engineering courses, $15.7 \%$ in technology courses and the remaining $1.8 \%$ enrolled in mathematics courses.

\section{A. Frequency analysis}

When asked about how the international students know about Malaysia, 56.6\% noted that they knew about Malaysia from shared information from their friends/relatives who have studied in Malaysia before, followed by $13.5 \%$ who knew about Malaysia as they studied in Malaysia and 9.6\% knew because they came for a vacation previously. Next, $7.8 \%$ get information about Malaysia from the news in papers and internet while $7.1 \%$ get information from their networking with Malaysian friends through social media such as Twitter and Facebook while $4.6 \%$ get information from education exhibition held at their home countries and remaining $0.7 \%$ get information from their government.

In terms of monthly household income, $77.6 \%$ of respondents have an income less than RM2500, followed by $11.7 \%$ were having income level between RM2501 to RM3500 while $7.1 \%$ have more than RM5000 monthly income, and 3.6\% have a range between RM3501 to RM5000. Out of 281 samples in this study, $50.9 \%$ students studied in Malaysia with financial support from family, $14.6 \%$ obtained a scholarship from their home country, $13.5 \%$ were self-financing, $12.1 \%$ obtained a scholarship from the Malaysian government, while the remaining $8.9 \%$ received scholarship and grants from their universities.

\section{B. Reliability analysis}

In doing survey type research, performing reliability analysis is essential to ensure the stability and consistency of the research instrument. As suggested in [42], if the values of Cronbach Alpha (CA) are between 0.6 to 0.79 , the reliability coefficient is considered acceptable, while the value of CA of above 0.8 is deemed to be excellent. Also, [43] suggested that for a CA with values, 0.5 to 0.7 indicates moderate reliability and values between the range of 0.7 to 0.90 indicates high reliability. In this study, as the CA values for all factors in this study ranged from 0.609 to 0.897 , it can be concluded that there was acceptable inter-item consistency reliability for each element in the independent variables.

Table 1: Summary of reliability coefficient

\begin{tabular}{|c|c|c|c|}
\hline $\begin{array}{l}\text { No. } \\
\text { of } \\
\text { Item }\end{array}$ & $\begin{array}{c}\text { Study } \\
\text { Variables }\end{array}$ & $\begin{array}{l}\text { Cronbac } \\
\text { h's Alpha }\end{array}$ & $\begin{array}{l}\text { Remark } \\
\mathrm{s}\end{array}$ \\
\hline \multicolumn{4}{|c|}{ Independent Variable } \\
\hline 4 & Perception & 0.609 & Acceptable \\
\hline 4 & Costs & 0.680 & Acceptable \\
\hline 4 & Reputation & 0.669 & Acceptable \\
\hline 4 & $\begin{array}{l}\text { Lecturers' } \\
\text { expertise }\end{array}$ & 0.825 & Good \\
\hline 4 & Facilities & 0.767 & Acceptable \\
\hline 4 & $\begin{array}{c}\text { Learning } \\
\text { environment }\end{array}$ & 0.816 & Good \\
\hline 4 & $\begin{array}{c}\text { Course } \\
\text { structure }\end{array}$ & 0.740 & Acceptable \\
\hline \multicolumn{4}{|c|}{ Dependent Variable } \\
\hline 12 & $\begin{array}{c}\text { International } \\
\text { students' } \\
\text { satisfaction }\end{array}$ & 0.897 & Good \\
\hline
\end{tabular}




\section{C.Descriptive statistical analysis}

Descriptive statistical analysis was designed to provide an overview of how each variable in the questionnaire was apparent to the respondents. Table 2 shows the perception of international students regarding selected services quality factors at the public HEIs. As the quality of higher education has become a crucial consideration for students to choose a HEI and plays a vital role in determining the HEI's reputation and brand name, concern for higher quality services is paramount for HEIs practitioners. Thus, this study was designed to determine which service quality factors that profoundly influence international student's satisfaction.

For all items in this study, the minimum number of respondents is 1.00 which indicates that some respondents strongly did not agree with those questions, either agreed or strongly agreed about the variable or strongly agreed with those questions using the scale from 1 to 7 . By looking at the mean values, the international students' perceptions of services quality factors in descending order are course structure, lecturers' expertise, learning environment, perception, facilities, reputation, and costs.

Finally, in terms of international students' satisfaction in this study, it reveals a mean of 4.96 , which means students somewhat agree that the service quality they received matched their perception and satisfaction level. In this study, the most concentrated variable among the independent variables is perception, whereby the standard deviation is the smallest (1.0723). Responses from this study were accepted and concentrated because the mean score ranges between 1.0723 to 1.3459 , indicating that all answers on the studied variables were considerably different among respondents thus, signifying that there are tolerable variances in responses.

Table 2: Summary of descriptive values

\begin{tabular}{|c|r|r|r|r|r|}
\hline Variables & $\mathrm{N}$ & $\begin{array}{r}\mathrm{M} \\
\text { in }\end{array}$ & $\begin{array}{r}\mathrm{M} \\
\text { ax }\end{array}$ & $\begin{array}{c}\text { Me } \\
\text { an }\end{array}$ & $\begin{array}{l}\text { Standa } \\
\text { rd } \\
\text { Deviation }\end{array}$ \\
\hline \multicolumn{5}{|c|}{ Independent Variable } \\
\hline Perception & 281 & 1.00 & 7.00 & 5.1130 & 1.0723 \\
\hline Costs & 281 & 1.00 & 7.00 & 4.5596 & 1.2903 \\
\hline Reputation & 281 & 1.00 & 7.00 & 4.7651 & 1.1567 \\
\hline $\begin{array}{c}\text { Lecturers' } \\
\text { Expertise }\end{array}$ & 281 & 1.00 & 7.00 & 5.2028 & 1.3459 \\
\hline Facilities & 281 & 1.00 & 7.00 & 4.8577 & 1.2661 \\
\hline $\begin{array}{c}\text { Learning } \\
\text { Environment }\end{array}$ & 281 & 1.00 & 7.00 & 5.1165 & 1.2202 \\
\hline $\begin{array}{c}\text { Course } \\
\text { Structure }\end{array}$ & 281 & 1.25 & 7.00 & 5.2046 & 1.1821 \\
\hline
\end{tabular}

\begin{tabular}{|c|c|c|c|c|c|}
\hline \multicolumn{3}{|c|}{ Dependent Variable } \\
\hline $\begin{array}{c}\text { Internatio } \\
\text { nal Students' } \\
\text { Satisfaction }\end{array}$ & 281 & 1.25 & 7.00 & 4.9629 & 1.20273 \\
\hline
\end{tabular}

\section{Correlation Pearson analysis}

Table 3 indicates the correlation matrices between variables. The Pearson correlation coefficient values results appear to be a positive correlation between all independent variables with the dependent variables. In [45] stated that rule of thumb for correlation coefficient, for values of 0.7 and above, is considered as a very strong relationship, 0.5-0.69 as a strong relationship, $0.3-0.49$ as a moderate relationship, $0.1-0.29$ as low relationship and 0.01 and below is categorized as a very low relationship.

To decide based on this sample whether there is any proof to suggest the population has a linear correlation, a significance test was performed by testing the null hypothesis where Ho: $\rho=0$ (no correlation in the population) and $\mathrm{H} 1$ : $\rho \neq 0$ (linear correlation is present). SPSS results with the correlation coefficient were significantly different from zero $(p<0.001)$. Therefore, it can be derived that there is a shred of reliable evidence to believe that perception, costs, reputation, lecturers' expertise, facilities, learning environment, and course structure are linearly correlated in international students' satisfaction. Results also indicate that all variables are positively correlated to another, signaling that the variables tend to increase together.

Results from this study also indicates that the strength of association between perception and the international students' satisfaction is strong $(\mathrm{r}=0.708, \mathrm{~N}=281, \mathrm{p}=0.000)$, correlation between costs and an international students' satisfaction is moderate relationship $(r=0.492, \mathrm{~N}=281$, $\mathrm{p}=0.000$ ), correlation between reputation and an international students' satisfaction is strong $(\mathrm{r}=0.601, \mathrm{~N}=281, \mathrm{p}=0.000)$, correlation between lecturers' expertise and an international students' satisfaction is very strong $(\mathrm{r}=0.780, \mathrm{~N}=281$, $\mathrm{p}=0.000$ ), correlation between facilities and an international students' satisfaction is strong $(\mathrm{r}=0.687, \mathrm{~N}=281, \mathrm{p}=0.000)$, correlation between learning environment and international students' satisfaction is very strong $(\mathrm{r}=0.768, \mathrm{~N}=281$, $\mathrm{p}=0.000$ ) and correlation between course structure and an international students' satisfaction is very strong $(\mathrm{r}=0.767$, $\mathrm{N}=281, \mathrm{p}=0.000$ ). In addition, the variables can be used for regression analysis as there is no multi-collinearity was detected for all correlation coefficient ( $r$ ) is less than .80 [42]-[44]. 
Table 3: Correlation statistics for all variable in the research framework

\begin{tabular}{|c|c|c|c|c|c|c|c|c|}
\hline & Pctn & Cost & Rep & LE & FC & $\begin{array}{c}\text { Lrn } \\
\text { Env }\end{array}$ & CS & ISS \\
\hline Pctn & 1 & & & & & & & \\
\hline Costs & $.475^{* *}$ & 1 & & & & & & \\
\hline Rep & $.456^{* * *}$ & $.486^{* * *}$ & 1 & & & & & \\
\hline LE & $.557^{* *}$ & $.371^{* *}$ & $.567^{* *}$ & 1 & & & & \\
\hline FC & $.504^{* *}$ & $.347^{* *}$ & $.523^{* *}$ & $.659^{* *}$ & 1 & & & \\
\hline Lrn Env & $.612^{* * *}$ & $.465^{* *}$ & $.594^{* *}$ & $.766^{* *}$ & $.600^{* *}$ & 1 & & \\
\hline CS & $.597^{* *}$ & $.471^{* *}$ & $.673^{* *}$ & $.736^{* *}$ & $.622^{* *}$ & $.671^{* *}$ & 1 & \\
\hline ISS & $.708^{* *}$ & $.492^{* *}$ & $.601^{* *}$ & $.780^{* *}$ & $.687^{* *}$ & $.768^{* *}$ & $.767^{* *}$ & 1 \\
\hline **. Correlation is significant at the 0.01 level (2-tailed). \\
Pctn (Perception), Rep (Reputation), LE (Lecturers' Expertise), FC (Facilities), Lrn Env (Learning Environment), CS (Course Structure), \\
ISS (International students' satisfaction)
\end{tabular}

\section{E. Multiple regression analysis}

Multiple Regression Analysis was employed to evaluate which services quality factors of higher education namely perception, costs, reputation, lecturers' expertise, facilities, learning environment, and course structure (independent variables) significantly influence the international students' satisfaction (dependent variable). It was hypothesized that hypotheses $\mathrm{H} 1, \mathrm{H} 2, \mathrm{H} 3, \mathrm{H} 4, \mathrm{H} 5, \mathrm{H} 6$, and $\mathrm{H} 7$ would be significantly related between independent variables and dependent variable. Table 4 indicates the multiple regression analysis results

Table 4: Relationship between the independent variables and dependent variable

\begin{tabular}{|c|c|c|c|c|c|c|l|}
\hline $\begin{array}{c}\text { Hypothe } \\
\text { ses }\end{array}$ & Model & B & $\begin{array}{c}\text { Std. } \\
\text { Error }\end{array}$ & $\begin{array}{c}\text { Beta } \\
(\beta)\end{array}$ & $\mathrm{t}$ & $\begin{array}{c}\text { P-Val } \\
\text { ue }\end{array}$ & Result \\
\hline H1 & Pctn - ISS & .266 & .043 & .237 & 6.121 & .000 & Significant \\
\hline H2 & Costs - ISS & .050 & .032 & .053 & 1.543 & .124 & Not Significant \\
\hline H3 & Rep - ISS & .007 & .042 & .007 & .175 & .861 & Not Significant \\
\hline H4 & LE - ISS & .200 & .046 & .224 & 4.352 & .000 & Significant \\
\hline H5 & FC - ISS & .147 & .038 & .155 & 3.899 & .000 & Significant \\
\hline H6 & $\begin{array}{c}\text { Lrn Env - } \\
\text { ISS }\end{array}$ & .188 & .048 & .191 & 3.913 & .000 & Significant \\
\hline H7 & CS - ISS & .210 & .050 & .206 & 4.174 & .000 & Significant \\
\hline $\begin{array}{l}\text { Note: *p < 0.05 Pctn (Perception), Rep (Reputation), LE (Lecturers' Expertise), FC (Facilities), Lrn Env (Learning Environment), } \\
\text { CS (Course Structure), ISS (International students' satisfaction) }\end{array}$ \\
(1)
\end{tabular}

Table 5: Model summary

\begin{tabular}{|c|c|c|c|c|}
\hline Model & $\mathrm{R}$ & $\begin{array}{c}\mathrm{R} \\
\text { Square }\end{array}$ & $\begin{array}{c}\text { Adjuste } \\
\mathrm{d} \text { R Square }\end{array}$ & $\begin{array}{c}\text { Std. Error of the } \\
\text { Estimate }\end{array}$ \\
\hline 1 & $.885^{\mathrm{a}}$ & .784 & .778 & .56610 \\
\hline \multicolumn{2}{|c|}{ Predictors: (Constant), perception, reputation, lecturers' } \\
expertise, facilities, learning environment, course structure \\
Dependent Variable: International students' satisfaction \\
\hline
\end{tabular}

In this study, the perception was found to have a statistically significant relationship on international students' satisfaction level because results of significance values exhibited that $\beta=.237$, and $p<0.05$. Positive beta on perception characteristic shows that the more the perception characteristics, the influence towards the international students' satisfaction of service quality in higher education will also be stronger. Thus, hypothesis $\mathrm{H} 1$ is accepted. The results supported the findings of [46] who suggested that Malaysia is a preferred destination among Asian students to pursue their education as they perceived that the adjustment process will be a lot easier due to the proximity of Malaysia to their home countries and similarity in culture and language, as well as the perception on the reputation of the universities, reasonable tuition fees and lower costs of living as compared to other higher education providers with equal or better quality. Similarly, in [35] added that Malaysia is regarded as a safe country to live and study with a stable government and modern facilities, which pull and motivate international students to come to Malaysia.

Next, surprisingly costs factor was found to have no statistically significant relationship towards international students' satisfaction as significance values resulted with $\mathrm{p}>0.05$. Thus, hypothesis $\mathrm{H} 2$ is rejected. This results, therefore, challenges previous findings as in [47] stating that price or tuition fees had a significant relationship with students' satisfaction and expectation of quality service and also as in [48] who proved that financial and economic consideration was positively related to international student's overall satisfaction of higher education. One possible reason for this finding is because the costs of living and studying in Malaysia is relatively low as compared to other developing and developed countries [49].

Similarly, reputation was also found to have no significant influence on international students' satisfaction as significance values resulted in $\square \mathrm{p} \square 0.05$. Thus, hypothesis H3 is also rejected. This finding, therefore, opposed the findings of [50], who stipulated that perceived quality and image have

Published By:

Blue Eyes Intelligence Engineering

\& Sciences Publication 
a substantial influence on students' satisfaction. Possible reasons that lead to these findings may be due to the perception of getting an overseas qualification is prestigious enough for international students to motivate them to study abroad, the international students' receptiveness of exploring new cultures and experiences [51], to escape the political instability and strict government policy on higher education or simply because of the difficulties to enter local HEIs in their home country [52]. Further investigation on this matter may be conducted in the future to get a better understanding of the actual reasons for their decision to study abroad and not in their home country.

The results also proved that lecturers' expertise could be used to predict international students' satisfaction as the significance values resulted in $\beta=0.224$ and $p<0.05$. Thus, hypothesis $\mathrm{H} 4$ is accepted. These results, therefore, correspond to proposals of [53], who stated that the quality of lecturers and academic staffs determine the quality of higher education and services quality of an institution. Therefore, when the quality meets the international students' perception and expectation, it will be most likely to increase their satisfaction level.

Subsequently, facilities were found to have a significant influence on international students' satisfaction because the positive beta means that the better facilities provided by the public HEIs, the higher its influence on international students' satisfaction level. Thus, hypothesis H5 is accepted. This finding is similar to [47], who proposed that the availability, accessibility, and higher quality of facilities, transportation, and security provided by HEIs will increase the students'

For learning environment, it was also found to have a significant influence on international students' satisfaction because significance values resulted with $\beta=0.251$, and $\mathrm{p}<0.05$. The positive beta means that the better learning environment provided will yield a higher level of international students' satisfaction. Thus, hypothesis H6 is accepted. This result corresponds as in [28] where learning environment factor was proved to have a significant relationship towards students' satisfaction and as in [54] who demonstrated that support facilities, class sizes, and classroom environment have a significant relationship towards student's satisfaction level.

Next, the course structure was also found to have a significant relationship towards international students' satisfaction level because significance values resulted in $\beta=0.2$, and $p<0.05$. The positive beta on this variable display that the better the course structure being planned, the higher the level of international students' satisfaction would be. Therefore, hypothesis H7 is accepted. Results of this study is similar to findings in [28] where courses offered by HEIs were proved to have a significant relationship on students' satisfaction, which signals to HEIs that, when designing the internationalization strategies, in terms of course offering, HEIs may want to identify courses that are popular and highly demanded by international students and offer high-quality programs with an interesting syllabus that is compatible with job market demand.

Hence, based on the regression analysis results in this study, it can be concluded that perception, lecturers' significance values resulted in $\beta=0.165$ and $p<0.05$. The satisfaction level.

expertise, facilities, learning environment, and course structure were proved to have a statistically significant relationship towards international students' satisfaction and can be used to predict international students' satisfaction reliably. Hence, hypotheses $\mathrm{H} 1, \mathrm{H} 4, \mathrm{H} 5, \mathrm{H} 6$, and $\mathrm{H} 7$ were supported because of $\mathrm{p}<0.05$. However, costs and reputation factor were proved to have no statistically significant relationship towards international students' satisfaction and therefore, cannot be used to reliably predict international students' satisfaction because of $\mathrm{p}>0.05$. Hence, H2 and H3 were rejected.

Finally, the beta weights suggested that perception factor, contribute most to the international students' satisfaction. As shown in Table 5, the multiple regression summary shows that there is a high degree of correlation $(R=0.885)$ between $\mathrm{X}$ and $\mathrm{Y}$. The coefficient of determination $\left(\mathrm{R}^{2}\right)$ indicates that $78.4 \%$ of the variance in the international students' satisfaction can be predicted from the independent variables in this study. The adjusted $\mathrm{R}^{2}$ attempts to yield a more honest value to estimate the $\mathrm{R}^{2}$ for the population, where in this case, it is $77.7 \%$, where according to [55], the effect size is large. The value covers more than half percentage covering the variation of service quality factors that influence the international students' satisfaction level in public HEIs (it indicates the proportion of variance in international students' satisfaction that can be described by all seven predictors). The overall results of the regression analysis proved that this study was well constructed, and it was able to represent the selected variables in this study [42]

\section{CONCLUSION}

Findings from the current study indicate that the learning environment factor is the most effective variable in influencing the international students' satisfaction level. Given the fact that Malaysian HEIs comprise students from diverse, multicultural, ethos and education background, HEIs should continuously improve and create a conducive and pleasant learning environment in the university setting that meet the international students' expectation such as first-class classroom facilities equipped with the latest ICT, and excellent quality of service delivery. Hence, it will most likely increase the international students' expectation and satisfaction level; making them believe that the money they spend is worthwhile. Also, it signals to HEIs management to always maintain and support two-way communication through joint activities and giving feedback on the quality of products and services to ensure continuous support and create a positive learning experience among international students. Positive word of mouth communication will only be useful if current students are satisfied with the HEIs service quality.

Results of this study also proved that except for cost and reputation, all other services quality namely perception, lecturers' expertise, faculties, learning environment, and course structure were found to be significantly influencing the international students' satisfaction level. Therefore, it signals to HEIs that as influential determinants of students' satisfaction vary across time and dimension, HEIs should 
continuously determine and understand what matters most to international students regarding the whole higher education system and continuously improve the overall quality of higher education.

In conclusion, findings of this study had added knowledge regarding the most influential determinants of an international students' satisfaction level towards Malaysian higher education quality services and, therefore, fill the gaps in literature regarding The Expectancy Disconfirmation Theory applicable in terms of services quality factors that can be used to predict the levels of international student's satisfaction in higher education. Findings from this study will be useful for HEIs' management to revitalize their internationalization strategy by strengthening their resources and capabilities and plan towards exceeding international students' expectations. Hence, HEIs will be able to attract more international students to further studies in Malaysia and help Malaysia to achieve the target of becoming the international hub of education excellence by the year 2025 [56].

\section{REFERENCES}

1. J. Williams and G. C. Ansfield, "Fitness for purpose? national and institutional approaches to publicising the student voice," Quality in Higher Education, 13(2), 2007, pp. 159-172.

2. J. Douglas and A. Douglas, "Evaluating teaching quality," Quality in Higher Education, 12(1), 2006, pp. 3-13.

3. R. L. Oliver, "A cognitive model of the antecedents and consequences of satisfaction decisions," Journal of Marketing Research, 17(4), 1980, pp. 460-469.

4. J. M. Carlsmith and E. Aronson, "Some hedonic consequences of the confirmation and disconfirmation of expectances," Journal of Abnormal and Social Psychology, 66(2), 1963, pp. 151-156.

5. J. T. E. Richardson, "Instruments for obtaining student feedback: A review of the literature," Assessment and

6. S. Arif, M. Ilyas, and A. Hameed, "Student satisfaction and impact of leadership in private universities," TQM Journal, 25(4), 2013, pp. 399-416.

7. H. S. Akareem and S. S. Hossain, "Determinants of education quality: What makes students' perception different?," Open Review of Educational Research, 3(1), 2016, pp. 52-67.

8. B. Sojkin, P. Bartkowiak, and A. Skuza, "Determinants of higher education choices and student satisfaction: The case of Poland," Higher Education, 2012, 63(5), pp. 565-581.

9. L. C. Duque, "A framework for analysing higher education performance: Students' satisfaction, perceived learning outcomes, and dropout intentions," Total Quality Management \& Business Excellence, 25(1-2), 2014, pp. 1-21.

10. L. Ledden, S. P. Kalafatis, and P. Samouel, "The relationship between personal values and perceived value of education," Journal of Business Research, 60(9), 2007, pp. 965-974.

11. J. Douglas, R. McClelland, and J. Davies, "The development of a conceptual model of student satisfaction with their experience in higher education," Quality Assurance in Education, 16(1), 2008, pp. 19-35.

12. K. M. Elliott and D. Shin, "Student satisfaction: an alternative approach to assessing this important concept," Journal of Higher Education Policy and Management, 24(2), 2002, pp. 197-209.

13. S. Raghavan, R. Ganesh, S. Raghavan, and R. Ganesh, Evaluation in Higher Education, 30(4), 2005, pp. 387-415.

"Addressing service quality to increase students' satisfaction and retention in Malaysian private higher education institutions," American Journal of Economics, 5(2), 2015, pp. 243-250.

14. M. K. Shahijan, S. Rezaei, and M. Amin, "International students' course satisfaction and continuance behavioral intention in higher education setting: an empirical assessment in Malaysia," Asia Pacific Education Review, 17(1), 2016, pp. 41-62.

15. L. W. Mai, "A comparative study between UK and US: The student satisfaction in higher education and its influential factors," Journal of Marketing Management, 21(7-8), 2005, pp. 859-878.

16. A. Gibson, "Measuring business student satisfaction: A review and summary of the major predictors," Journal of Higher Education Policy and Management, 32(3), 2010 pp. 251-259.

17. F. Ali, Y. Zhou, K. Hussain, P. K. Nair, and N. A. Ragavan, "Does higher education service quality effect student satisfaction, image, and loyalty? A study of international students in Malaysian public universities," Quality Assurance in Education, 24(1), 2016, pp. 70-94.

18. M. W. Migin, M. Falahat, M. S. A. Yajid, and A. Khatibi, "Impacts of institutional characteristics on international students' choice of private higher education institutions in Malaysia," Higher Education Studies, 5(1), 2015, pp. 31-42.

19. R. Wadhwa, "Students on move: Understanding decision-making process and destination choice of Indian students," Higher Education for the Future, 3(1), 2016, pp. 54-75.

20. M. Hübner, "Do tuition fees affect enrollment behavior? Evidence from a 'natural experiment' in Germany," Economics of Education Review, 31(6), 2012, pp. 949-960.

21. S. Farahmandian, H. Minavand, and M. Afshardost, "Perceived service quality and student satisfaction in higher education," Journal of Business and Management, 12(4), 2013, pp. 65-74.

22. J. Hemsley-Brown, T. C. Melewar, B. Nguyen, and E. J. Wilson, "Exploring brand identity, meaning, image, and reputation (BIMIR) in higher education: A special section," Journal of Business Research, 69(8), 2016, pp. 3019-3022.

23. C. Dennis, S. Papagiannidis, E. Alamanos, and M. Bourlakis, "The role of brand attachment strength in higher education," Journal of Business Research, 69(8), 2016, pp. 3049-3057.

24. K. T. Soo and C. Elliott, "Does price matter? overseas students in UK higher education," Economics of Education Review, 29(4), 2010, pp. 553-565.

25. P. Lenton, "Determining student satisfaction: An economic analysis of the National Student Survey," Economics of Education Review, 47, 2015, pp. 118-127.

26. H. Alves, and M. Raposo, "Conceptual model of student satisfaction in higher education," Total Quality Management, 18(5), 2007, pp. 571-588.

27. S. Wilkins, M. M. Butt, D. Kratochvil, and M. S Balakrishnan, "The effects of social identification and organizational identification on student commitment, achievement and satisfaction in higher education," Studies in Higher Education, 41(12), 2016, pp. 2232-2252.

28. B. Z. Butt, and K. U. Rehman, "A study examining the students' satisfaction in higher education," Procedia-Social and Behavioral Sciences, 2(2), 2010, pp. 5446-5450. 
29. S. Alam Malik, S. Hassan, and M. Z. Iqbal, "Measuring students' perceptions and expectations in business schools of Pakistan," Asian Education and Development Studies, 1(3), 2012, pp. 222-236.

30. M. E. Malik, R. Q. Danish, and A. Usman, "The impact of service quality on students' satisfaction in higher education Institutes of Punjab," Journal of Management Research, 2(2), 2010, pp. 1-11.

31. B. Crose, "Internationalization of the higher education classroom: strategies to facilitate intercultural learning and academic success," International Journal of Teaching and Learning in Higher Education, 23(3), 2011, pp. 388-395.

32. O. Ogunnaike, B. Tairat, and J. Emmanuel, "Customer relationship management approach and student satisfaction in higher education marketing," Journal of Competitiveness, 6(3), 2014, pp. 49-62.

33. T. Gruber, S. Fuß, R. Voss, and M. Gläser-Zikuda, "Examining student satisfaction with higher education services: Using a new measurement tool," International Journal of Public Sector Management, 23(2), 2010, pp. 105-123.

34. M. M. Lai, S. H. Lau, N. A. Mohamad Yusof, and K. W. Chew, "Assessing antecedents and consequences of student satisfaction in higher education: Evidence from Malaysia, " Journal of Marketing for Higher Education, 25(1), 2015, pp. 45-69.

35. S. Z. Ahmad, and F. R. Buchanan, "Motivation factors in students' decision to study at international branch campuses in Malaysia," Studies in Higher Education, 42(4), 2017, pp. 651-668.

36. K. Kelley, B. Clark, V. Brown, and J. Sitzia, "Good practice in the conduct and reporting of survey research," International Journal for Quality in Health Care, 15(3), 2003, pp. 261-266.

37. A. Tan, "College choice behaviors of international students," SAGE Open, 5(4), 2015, pp. 1-14.

38. G. A. Churchill Jr, and J. P. Peter, "Research design effects on the reliability of rating scales: A meta-analysis," Journal of Marketing Research, 21(4), 1984, pp. 360-375.

39. J. W. Creswell, and J. D. Creswell, Research Design: Qualitative, Quantitative, and Mixed Methods Approaches. Los Angeles: Sage Publications, 2017.

40. F. Faul, E. Erdfelder, A. Buchner, and A. G. Lang, "Statistical power analyses using $\mathrm{G}^{*}$ Power 3.1: Tests for correlation and regression analyses," Behavior Research Methods, 41(4), 2009, pp. 1149-1160.

41. J. F. Hair Jr, A. H. Money, P. Samouel, and M. Page, Research Methods for Business, England: John Wiley and Sons, 2007.

42. U. Sekaran and R. Bougie, Research Methods for Business: A Skill Building Approach. New Jersey: John Wiley and Sons, 2016.

43. P. R. Hinton, B. Charlotte, M. Isabella, and C. Bob, SPSS Explained. New York: Routledge, 2004.

44. D. R. Cooper, P. S. Schindler, and J. Sun, Business Research Methods. New York: McGraw-Hill, 2006.

45. A. Osman, Y. Othman, S. M. S. Rana, M. Solaiman, and B. Lal, "The influence of job satisfaction, job motivation and perceived organizational support towards organizational citizenship behavior (OCB): A perspective of American-based organization in Kulim, Malaysia," Asian Social Science, 11(21), 2015, pp. 174-182.

46. J. K. Nachatar Singh, J. Schapper, and G. Jack, "The importance of place for international students' choice of university: A case study at a Malaysian university," Journal of Studies in International Education, 18(5), 2014, pp. $463-474$.

47. L. M. Hasan and R. Masri, "Factors influence the satisfaction of international students at private universities in Malaysia," International Journal of Science and
Research, 4(8), 2015, pp. 136-142.

48. T. Ngamkamollert and A. Ruangkanjanases, "Factors influencing foreign students' satisfaction toward international program in Thai universities," International Journal of Information and Education Technology, 5(3), 2015, pp. 170-178.

49. Ministry of Education Malaysia, Malaysia Education Blueprint 2015-2025 (Higher Education), Putrajaya: Ministry of Education Malaysia, 2015.

50. L. Temizer and A. Turkyilmaz, "Implementation of student satisfaction index model in higher education institutions," Procedia-Social and Behavioral Sciences, 46, 2012, pp. 3802-3806.

51. B. Y. Farhan, "Tuition elasticity of demand as a tool to manage higher education institutions," International Journal of Arts and Sciences, 9(1), 2016, pp. 159-172.

52. P. Zheng, "Antecedents to international student inflows to UK higher education: A comparative analysis," Journal of Business Research, 67(2), 2014, pp. 136-143.

53. P. Naidu and N. E. S. Derani, "A comparative study on quality of education received by students of private universities versus public universities," Procedia Economics and Finance, 35, 2016, pp. 659-666.

54. M. Yusoff, F. McLeay, and H. Woodruffe-Burton, "Dimensions driving business student satisfaction in higher education," Quality Assurance in Education, 23(1), 2015, pp. 86-104.

55. J. Cohen, Statistical Power Analysis for the Behavioral Sciences. New York: Academic Press, 1988

56. M. I. A. Aziz and D. Abdullah, "Finding the next 'wave' in internationalisation of higher education: Focus on Malaysia," Asia Pacific Education Review, 15(3), 2014 pp. 493-502. 